\title{
Neotectonic evolution of the Eastern Mediterranean region
}

\author{
Oğuz Göğüşs ${ }^{1}$ Ömer Emre ${ }^{2} \cdot$ Hasan Sözbilir ${ }^{3}$
}

Accepted: 11 November 2020 / Published online: 3 December 2020

(c) The Author(s), under exclusive licence to Springer Nature Switzerland AG part of Springer Nature 2020

It is our pleasure to introduce you the special issue in the Mediterranean Geoscience Reviews titled as Neotectonic Evolution of the Eastern Mediterranean Region dedicated to Dr Fuat Şaroğlu, who made immense contributions to our understanding on active faulting, earthquake hazards, and the neotectonic evolution of the Anatolian lithosphere and its plate boundaries. Anyone who deals with the intricate geological problems of this part of the world where three of the world's tectonic plates interact with each other (Africa-Eurasia-Anatolia) would appreciate the findings of Şaroğlu's work because often times they reveal themselves to be the key elements of the Eastern Mediterranean's tectonic framework. Notably, Şaroğlu is one of the founders of the Active Fault Map of Turkey (1992) where today this accounts as a generic reference for researchers from diverse backgrounds of Earth Sciences and related fields, such as, geodesy, structural geology, morphotectonics, seismology, petrology, stratigraphy and geodynamics.

Oğuz Göğüş

goguso@itu.edu.tr

1 Eurasia Institute of Earth Sciences, Istanbul Technical University, Istanbul, Turkey

2 FUGRO-SIAL Geosciences Consulting and Engineering, Ankara, Turkey

3 Geological Engineering, Dokuz Eylül University, Izmir, Turkey

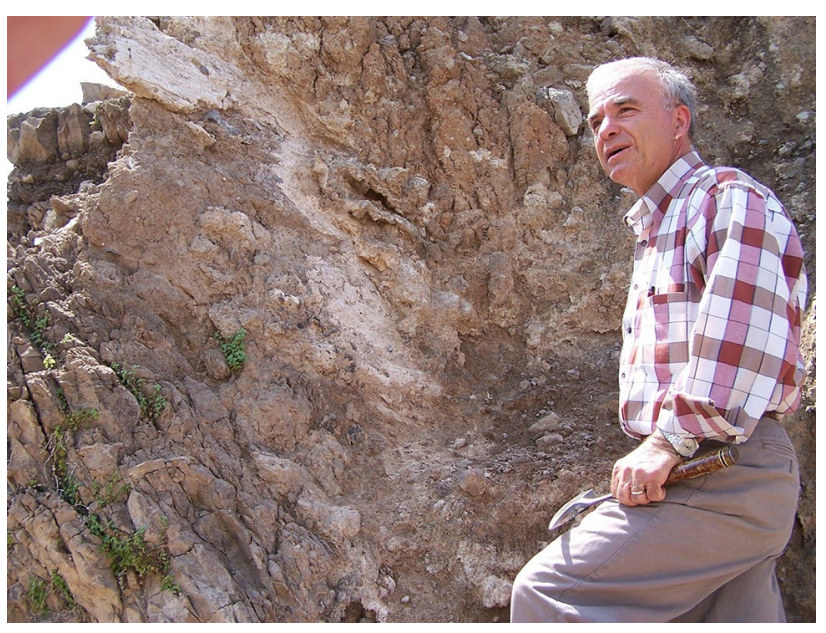

Fuat Şaroğlu was born on the 16th of January in 1945 in Mardin/Southeast Turkey. He completed his B.Sc. in Geology at the department of Earth Sciences in Istanbul University in 1969 and this followed obtaining M.Sc. at the same department in 1972. He completed his Ph.D. in 1986 under the supervision of Prof. Yücel Yilmaz, a leading figure in the Geology of Turkey, with dissertation title Structural and Geological evolution of East Anatolia during Neotectonics period. In his Ph.D., Şaroğlu conducted field studies nearly across the entire East Anatolian Plateau where he meticulously documented NE-SW and NW-SE oriented strike slip and E-W thrust fault systems, and related basins, formed as a response to the Arabia-Eurasia plate convergence. This was one of the earlier studies that show how plate shortening in the collision systems deforms the crust in the Anatolian segment of the Alpine orogeny where accretion, escape tectonics and magmatism prevails.

Between 1969 and 1995, Şaroğlu worked in the Geology Department of MTA (General Directorate and Mineral Research and Exploration) where he and his research team carried out field studies and active fault mapping throughout the entire country. His professional career continued after his retirement from MTA and took position at Turkish 
Petroleum (TPAO) between 1996 and 2003. While working as a consultant for various companies, he was invited to give lecture series as a visiting scholar at Çukurova, Hacettepe, Osmangazi, and Ankara Universities. He acted as a member of National Earthquake Council and Advisory Board of Turkey for the period of 2000-2012.

Şaroğlu's earliest contributions in active tectonics of Turkey, considered as pioneering work for the geological evolution of the East Anatolian region titled as The East Anatolian Fault System: Thoughts on its Development was published in MTA's bulletin with Esen Arpat in 1972. Here, the East Anatolian Fault, eastern boundary of the Anatolian plate, stretching to the Dead Sea Fault system in the Levant region was first recognized and strike slip characteristics of this fault system has been documented through field evidences including surface breaks associated with the M7 earthquake in 1971, epicenter in Bingöl region. Soon after this, with Nafi Toksöz (MIT) and Esen Arpat, Şaroğlu published a Nature article where rupture geometry and seismological characteristics of the Çaldıran earthquake $(\mathrm{Ms}=7.3,24.11 .1976)$ in the East Anatolia was identified. Further, with Celal Şengör and Naci Görür he published a seminal paper in 1985 on the strike slip faulting related basin formation in zones of tectonic escape. Since then there are plenty of reference maps/reports published by Şaroğlu and his colleagues on the tectonics of East Anatolia and, in general, active faulting in Turkey.

The collection of articles published in this volume were presented during the 72th Geological Congress of Turkey, held in Ankara, January 2019 in a session, organized as an expression of appreciation to Dr Fuat Şaroğlu. Duman et al. document the paleoseismological records of the Sürgü-Misis segment of the East Anatolian Fault system, pertaining to the active tectonics of this region. Emre et al. present data for segment structure of Merzifon-Esençay Fault that is one of the major dextral strike-slip fault splays bifurcating from the main strand of the North Anatolian Fault and paleoseismological findings on Esençay segment. Şengör and Yazıcı examine the factors that control the westward motion of the Anatolian Scholle and the geological evolution of this region in the context of boundary $v s$ body forces, acting upon it. Tatar et al. provide a detailed account of investigations on the activity of the East Anatolian Fault by focusing on the Sivrice earthquake (Jan, 24, 2020) as well as its associated surface breaks, morphological (landscape) and seismological characteristics. By using seismological, petrological and gravity data from satellite, McKenzie postulates that the elastic thickness of the lithosphere beneath the Eastern Mediterranean region and the Middle East is less than $5 \mathrm{~km}$ and the mantle convection expression is in spoke pattern planform. Yilmaz shows how morphotectonic evolution of the Adana plain in southern Anatolia has been controlled by the changing stress field and regional tectonics of the Southeast Anatolian orogenic area.

It is hard to provide a brief account on Şaroğlu's overall contributions to the geology of Turkey in this short letter. $\mathrm{He}$ is simply regarded as a prominent figure in geological community and more importantly it was his generosity and unconditional support to younger generation of researchers that made him an outstanding geologist and a friend. 